\title{
Perjuangan Pemberantasan Buta Aksara Huruf Ijaiyyah Pada Kaum Ibu
}

\author{
Kholifatul Fauziah ${ }^{1}$ \& Syah Amelia Manggala Putri² \\ 1,2 Program Studi Komunikasi Penyiaran Islam, Fakultas Agama Islam, Universitas Muhammadiyah Yogyakarta, \\ Jl. Brawijaya, Tamantirto Kasihan Bantul Yogyakarya \\ Email1: kholifatul.fauziyah@umy.ac.id \\ DOI: 10.18196/ppm.34.290
}

\begin{abstract}
Abstrak
Program intensif pemberantasan buta aksara pada kaum ibu Jamaah Pengajian Masjid Al Mubarok ini ditujukan untuk mengurangi tingkat buta aksara huruf Arab (hijaiyyah) di lingkungan sekitar kampus Universitas Muhammadiyah Yogyakarta. Sasaran kegiatan ini adalah kaum Ibu yang merupakan anggota jamaah pengajian Masjid Al Mubarak, RT oo2, Tegalrejo, Tamantirto, Kasihan, Bantul. Studi pendahuluan melalui uji kompetensi dasar menunjukkan bahwa sekitar 95\% peserta belum mampu membaca sebagian huruf-huruf hijaiyah secara sempurna sesuai tajwid. Oleh karena itu, kegiatan ini bertujuan untuk mengajarkan sekaligus me-review kompetensi warga belajar dalam membaca Al-Quran melalui metode CBSA (Cara Belajar Santri Aktif) Buku Iqra yang dilakukan selama 20 kali pertemuan. Selain itu, kegiatan pengabdian ini juga diperluas dengan pengembangan manajemen pelaksanaan program sekaligus peningkatan motivasi warga belajar untuk selalu bersemangat menuntut ilmu. Peserta aktif dari kaum ibu dengan indikator menghadiri pelatihan sekurang-kurangnya 10 kali pertemuan (50\% dari total pertemuan) ada 16 orang. Adapun peserta yang dinyatakan berhasil mengenal dan melafadzkan huruf hijayyah sesuai makharijul huruf-nya pada pelatihan buta aksara huruf hijaiyyah tingkat dasar ini ada 12 orang. Dengan prosentase keberhasilan sebesar 75\%, dapat disimpulkan bahwa program ini telah berhasil meningkatkan kapasitas melek aksara huruf hijaiyyah secara efektif dan perlu untuk dilanjutkan.
\end{abstract}

Kata Kunci: Perjuangan, Buta Aksara, Huruf Hijaiyyah, Kaum Ibu, Metode Iqra.

\section{Pendahuluan}

Illiterasi atau buta aksara merupakan salah satu bencana kemanusiaan (Lal, 2015 dan Tengal, 2013). Iliterasi atau buta aksara adalah kurangnya kemampuan dalam membaca, menulis dan berhitung. Ketidakmampuan tersebut berpotensi mengurangi kapabilitas seseorang dalam menjalankan fungsi-fungsi sosialnya secara efektif dalam masyarakat. Pada aspek individu yang paling mendasar, literasi mempengaruhi fungsi kognitif. Secara khusus, belajar membaca misalnya, dapat meningkatkan dan memodifikasi kemampuan dasar tertentu, seperti memori verbal dan visual, keterampilan visuospasial dan visuomotor, serta keadaran fonologis (Ardila, dkk, 2010). Secara umum, belajar aksara merupakan perjuangan untuk mengembangkan dan memperkuat jalur-jalur yang digunakan oleh otak untuk memecahkan masalah. Selain itu, penderita buta aksara dapat menderita kerugian berupa penghinaan, kelaparan, hingga kemiskinan (Tengal 2013).

Sayangnya, bukan hanya di Indonesia, buta aksara telah menjadi bencana yang melanda seluruh dunia. Diperkirakan ada 770 juta orang di seluruh dunia yang masih menderita buta aksara dengan dua pertiga di antaranya adalah kaum perempuan (Lal, 2015). Selain itu, angka pemberantasan buta aksara juga menemui tantangan pada segmen usia dewasa. Tingkat keberhasilan pemberantasan buta aksara pada segmen ini cenderung mengecewakan (Abadzi, 2003). Dengan demikian, kelompok perempuan dewasa merupakan target pemberantasan buta aksara yang memerlukan perhatian lebih dibandingkan dengan kelompok dari sisi jenis kelamin serta usia yang lain.

Berdasarkan analisis situasi yang dilakukan bersama bagian pendidikan takmir Masjid Al Mubarok, jamaah perempuan memerlukan pelatihan baca Al-Quran karena hampir semua anggota jamaah belum pernah mengikuti pelatihan baca Al-Quran selain yang mereka dapatkan saat mengaji di waktu kecil. Alhasil, berdasarkan uji kompetensi dasar awal, mereka yang mampu membaca Al-Quran sekalipun belum bisa melafadzkan semua huruf hijaiyyah secara 
sempurna sewaktu diminta membaca Iqra jilid 1. Di samping itu, sekitar 15\% anggota jamaah yang datang saat uji kompetensi dasar awal belum mengetahui atau lupa sama sekali sebagian besar huruf hijaiyyah,bukan hanya tidak mampu melafadzkannya secara sempurna.Oleh karena itu, pelatihan ini diselenggarakan untuk memberantas buta aksara huruf hijaiyyah pada kaum ibu yang menjadi sasaran pengabdian.

Metode Iqra merupakan teknik membca Al-Quran dengan menggunakan buku Iqra jilid 1 sampai 6 sesuai dengan kebutuhan (Syaifulloh, 2013). Metode ini bertujuan untuk meningkatkan kemampuan membaca Al-Quran secara tartil melalui pelafalan huruf-huruf hijaiyyah yang benar (Astutik, 2012). Untuk itu, pengabdi merekomendasikan pelatihan baca Al-Quran tahap awal melalui jilid 1 buku Iqra agar para peserta belajar dapat membaca setiap huruf hijaiyyah dengan baik. Hal ini mengacu pada kesimpulan hasil uji pendahuluan di mana sebagain besar peserta belajar belum bisa melafadzkan huruf-huruf hijaiyyah sesuai dengan tempat keluar hurufnya.

\section{Metode Pelaksanaan}

Dalam pelaksanaan program pelatihan buta aksara huruf hijaiyyah ini, pengabdi bersama takmir masjid Al Mubarok, khususnya bagian pendidikan, menerapkan langkah-langkah sebagai berikut:

1) Pemilihan tutor baca Al-Quran. Tutor dipilih berdasarkan kerangka pengalaman dan pengetahuan membaca Al-Qur'an dan penguasaan terhadap metode Iqra. Jumlah tutor didiskusikan dengan bagian pendidikan takmir Masjid Al Mubarok dengan menyesuaikan jumlah peserta yangterundang pada pertemuan pertama yang memuat uji pendahuluan.

2) Pengabdi menggelar uji pendahuluan. Hal ini dilakukan untuk memvalidasi rencana pelaksanaan program sekaligus memastikan efektifitas kegiatan dengan membandingkan hasil uji pendahuluan ini dengan hasil pencapaian peserta didik pada akhir program.

3) Pelatihan baca Al-Quran yang mempertemukan masing-masing peserta dengan tutor menggunakan metode Iqra. Oleh karena itu, meskipun diselenggarakan seperti pengajian kelas besar, setiap peserta belajar secara privat dengan tutor. Secara spesifik, pelatihan ini bertujuan untuk menuntaskan kemampuan membaca huruf hijaiyaah sebanyak $50 \%$ dari peserta aktif pelatihan. Peserta tergolong dalam peserta aktif jika mengikuti sekurang-kurangnya 10 kali pertemuan dengan tutor yang dibuktikan dengan presensi kehadiran. Angka prosentase itu ditentukan setelah melihat bahwa sebagian profil demografis peserta belajar yang terdiri atas para lansia serta memiliki kekurangan fisik pada kontur lisan akibat stroke maupun karena lama tidak bersentuhan secara intensif dengan Al-Quran. Pelatihan di awali dengan pembukaan, doa akan belajar, membaca Al Fatihah, peserta membaca secara bergantian dengan tutor, taushiyah, doa penutup majelis dan penutup.

4) Pengembangan manajemen program. Untuk memastikan agar tujuan serta target tujuan dapat tercapai, diperlukan pengembangan administrasi program seperti penyiapan presensi, penyelenggaraan uji pendahuluan kompetensi dasar, menyiapkan kartu prestasi untuk me-review perkembangan belajar peserta belajar, serta evaluasi hasil pembelajaran dengan rekapitulasinya. Pengembangan administrasi program tersebut merupakan hasil verifikasi manajemen program pada tahap perencanaan melalui analisis masalah yang dilakukan dengan melakukan segmentasi jamaah yang dituju, pemetaan profil jamaah yang dituju, asesmen kebutuhan hingga prioritasi kebutuhan. Selanjutnya, analisis masalah tersebut diverifikasi dengan wawancara yang dilakukan terhadap ketua, perwakilan dari bagian pendidikan, perwakilan dari bagian saran dan prasarana takmir 
Masjid Al Mubarok sehingga tercipta kesepahaman perihal hal-hal administratif yang diperlukan dan teknis-teknis pelatihan yang akan dilakukan.

5) Pemberian motivasi belajar. Sebagai bagian dari sistem pendidikan informal, fluktuasi kehadiran peserta menjadi tantangan tersendiri dalam program ini. Oleh karena itu, pengabdi juga menyelenggarakan sesi taushiyah untuk memberikan motivasi belajar sebelum pelatihan ditutup setiap harinya. Harapannya, tingkat kedatangan peserta mengalami stagnasi dan tidak mengalami degradasi.

\section{Hasil dan Pembahasan}

Program pelatihan baca Al-Quran ini diselenggarakan setiap pekan sekali mulai 15 Oktober 2019 sampai 10 Maret 2020 sebanyak 20 kali pertemuan. Pada akhir program, rekapituasi kehadiran menunjukkan bahwa total peserta aktif yang mengikuti pelatihan sekurang-kurangnya $50 \%$ dari total pertemuan ada 16 orang. Dari 16 orang tersebut, 12 di antaranya dianggap berhasil membaca huruf-huruf hijaiyyah dengan pelafalan yang baik. Hal ini ditunjukkan dengan lolosnya peserta belajar dari EBTA Jilid 1 Buku Iqra yang terekap pada perkembangan belajar yang diakumulasi dari hasil akhir pada kartu prestasi para peserta belajar. Dengan demikian, prosentase kelulusan peserta belajar dari program ini adalah 75\%. Hal tersebut jauh melampaui target awal kelulusan yang hanya mencanangkan tingkat kelulusan peserta belajar pada angka $50 \%$.

Tingkat prosentase kelulusan peserta belajar di atas membuktikan bahwa program ini telah berjalan secara efektif. Pasalnya, tingkat keberhasilan program melampaui target awal yang ditetapkan. Hal ini sesuai dengan prinsip quality management yang menyebutkan bahwa efektivitas merujuk pada "doing right things" di mana pihak manajemen menyeleksi dan memfokuskan diri pada upaya memproduksi kegiatan-kegiatan untuk mencapai tujuan yang diinginkan (Sunqvist, dkk, 2014).

Selain itu, efektifitas program ini juga ditengarai oleh dampaknya yang membuat peserta menyukai atau senang belajar membaca Al-Quran. Kinerja belajar yang tinggi dan sikap aktif dalam belajar menjadi indikator atas temuan tersebut (Putra, 2018) Kinerja belajar dapat dilihat dari tingkat keberhasilan program yang melampaui target yang diharapkan. Adapun sikap aktif tercermin dari rekapitulasi kehadiran yang menunjukkan bahwa total peserta belajar ada 19 orang. Dari 19 orang tersebut, 16 di antaranya menjadi peserta aktif. Artinya, prosentase peserta belajar aktif adalah 84\%. Pengabdi menemukan bahwa sebanyak 13 orang peserta aktif menghadiri sekurang-kurangnya 16 kali pertemuan dari 20 kali pertemuan yang diselenggrakan. Perbandingan antara frekuensi jumlah kehadiran dengan jumlah peserta dapat dilihat pada grafik 1. di bawah ini: 


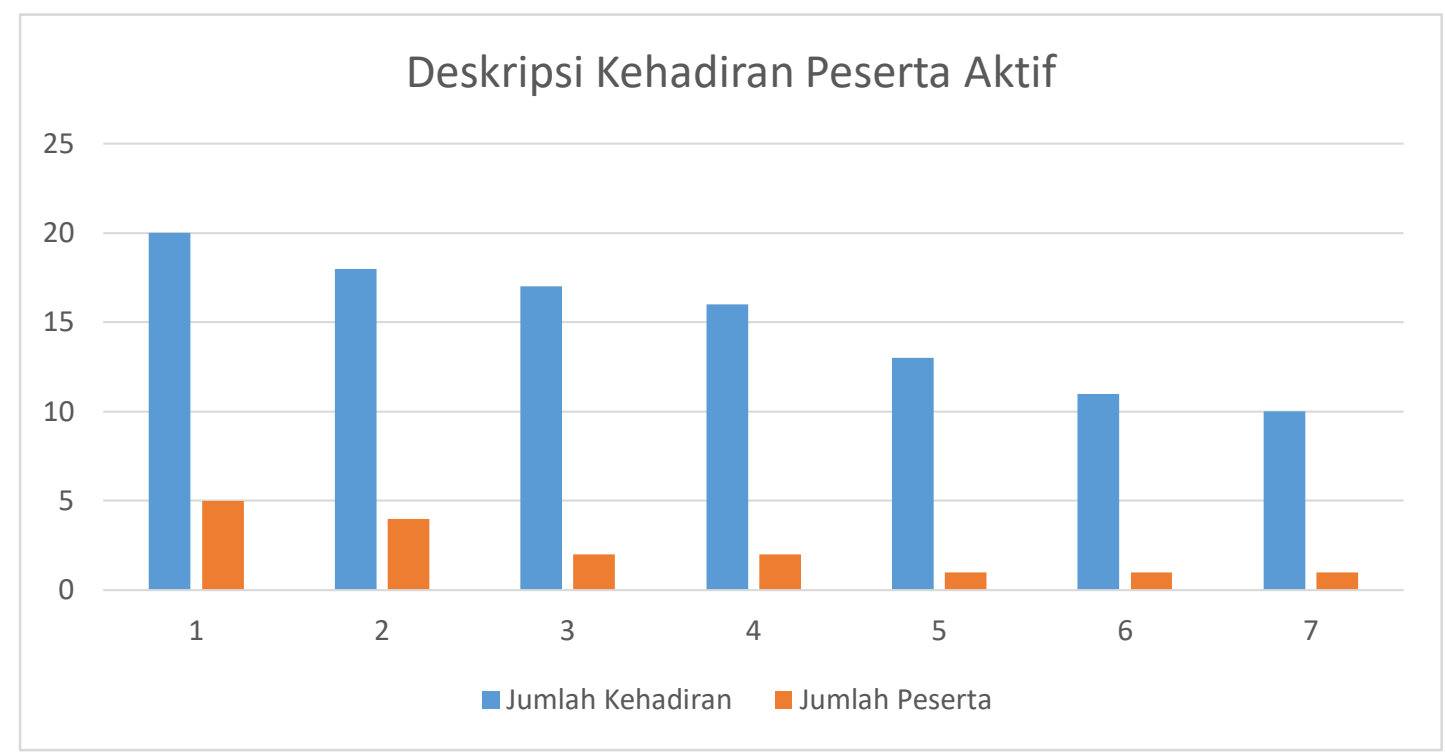

Grafik 1. Deskripsi Kehadiran Peserta Aktif

Grafik 1. di atas memberikan gambaran sikap aktif peserta belajar di dalam mengikuti pelatihan yang menjadi indikator lain efektivitas program pelatihan buta aksara huruf hijaiyyah ini.

Elemen ketiga yang mengindikasikan efektivitas program ini dalah hasil survey tingkat kepuasan mitra pengabdian oleh perwakilan bagian pendidikan takmir Masjid Al Mubarok. Istilah kepuasan dalam hal in merujuk pada keadaan emosional yang menyenangkan dalam menghadapi apa yang sebenarnya diterima dibandingkan dengan apa yang seharusnya diterima (Zanah dan Sulaksana, 2016). Dalam hal ini, pengisian survey tingkat kepuasan menunjukkan bahwa pihak mitra merasa puas dengan hasil pengabdian yang sesuai dengan solusi yang diharapkan mitra serta dapat dimanfaatkan secara maksimal.

Elemen terakhir yang menunjukkan efektivitas program ini ditunjukkan oleh hasil wawancara dengan perwakilan bagian pendidikan takmir Masjid Al Mubarok yang telah memiliki gambaran lanjutan pelaksanaan program baca Al-Quran hingga level tadarrus. Selain itu, program pelatihan ini juga telah dijadikan program tetap pekanan masjid Al Mubarok. Sayangnya, program pelatihan ini terpaksa dihentikan sementara akibat pandemi Covid-19. Hal itu berlaku juga bagi sebagian besar program-program takmir Masjid Al Mubarok yang mengindikasikan adanya kerumunan orang di dalam masjid.

\section{Simpulan}

Berdasarkan hasil di atas, dapat disimpulkan bahwa program pelatihan ini telah berjalan secara efektif. Hal ini ditunjukkan oleh indikator-indikator berikut:

1) Sebanyak 12 orang peserta aktif dari total 16 orang berhasil melalui EBTA Jilid 1 Buku Iqra. Prosentase peserta belajar yang berhasil melalui EBTA ini adalah 75\%. Prosentase tersebut melebihi tujuan awal pelatihan yang berada pada angka $50 \%$.

2) Hasil survey kepada mitra pengabdian yang menunjukkan bahwa mitra merasa puas dengan berlangsungnya program pengabdian masyarakat ini.

3) Adanya gambaran tindak lanjut yang berasal dari bagian pendidikan takmir Masjid Al Mubarok dan peserta belajar untuk melanjutkan program pada tahap berikutnya. 


\section{Ucapan Terima Kasih}

Pengabdi mengucapkan terima kasih dan memberikan apresiasi pada pihak-pihak yang terlibat pada program pengabdian ini. Pihak-pihak yang terlibat dalam pengabdian ini meliputi:

1. LP3M UMY selaku penyokong dana pengabdian.

2. Sakinatudhuhuriyyah, S.Kom.I dan Nikmatus Saidah, S.Kom.I yang telah bersedia menjadi tutor pelatihan baca Al-Quran.

3. Takmir Masjid Al Mubarok yang telah memfasilitasi pelatihan.

4. Semua peserta belajar kaum Ibu jamaah Masjid Al Mubarok yang masih terhubung hingga kini.

\section{Daftar Pustaka}

Astutik. (2012). Pengaruh Metode Iqra Terhadap Kemampuan Anak Dalam Membaca Al Qur'an Secara Fasih dan Tartil Siswa TPQ Tasywiqussalaf Jleper Mijen Demak. Skripsi, Prodi Pendidikan Guru Madrasah Ibtida'iyah, IAIN Walisongo, Semarang.

Lal, B. Suresh. (2015). The Economic and Social Cost of Illiteracy: An Overview. IJARIIE-ISSN (O) 2395-4396.

Putra, Anshari. (2018). Pembelajaran Buta Aksara Berbasis Inovasi Di Desa Air Hitam. Jurdimas, 1(1), 52-56.

Sunqvist, Erik, dkk (2014). What is Project Efficiency and Effectiveness?. Procedia, (119), 278-287.

Syaifulloh, Ahmad. (2013). Efektivitas Metode Iqra Dalam Pembelajaran Al-Quran Di MI Ma'arif Sembego, Sleman, Yogyakarta. Skripsi, Prodi Pendidikan Guru Madrasah Ibtidaiyah, UIN Sunan Kalijaga, Yogyakarta.

Tengal, Niranjan. (2013). Social and Economic Consequences of Illiteracy. International Journal of Behavioral Social and Movement Sciences, 2(2).

Zana, Rifki Faisal M dan Sulaksana, Jaka. (2016). Pengaruh Fungsi Manajemen Terhadap Kepuasan Kerja Karyawan (Studi Kasus di Home Industry Asri Rahayu di Wilayah Majalengka). Jurnal Ilmu Pertanian dan Peternakan, 4(2). 